\title{
School Production Unit and Consultancy Services: Many-sided Beneficial Requirement Overly Neglected in TVET Institutions
}

\author{
Daniel Uchenna Chukwu ${ }^{1}$, Hyginus Osita Omeje ${ }^{1}$, Patrick Sunday Oyaimare Uddin 2, *, \\ Anayo Alagba Okepka ${ }^{3}$ \\ ${ }^{1}$ Department of Industrial Technical Education, University of Nigeria, Nsukka, Nigeria \\ ${ }^{2}$ Department of Vocational and Technical Education, Ambrose Alli University, Ekpoma, Nigeria \\ ${ }^{3}$ Directorate of Force Education, Nigeria Police College, Owerri, Nigeria
}

Email address:

chukwu.daniel@unn.edu.ng (D. U. Chukwu), hyginus.omeje@unn.edu.ng (H. O. Omeje), uddinpatrick@gmail.com (P. S. O. Uddin), okekpaa@gmail.com (A. A. Okepka)

${ }^{*}$ Corresponding author

\section{To cite this article:}

Daniel Uchenna Chukwu, Hyginus Osita Omeje, Patrick Sunday Oyaimare Uddin, Anayo Alagba Okepka. School Production Unit and Consultancy Services: Many-sided Beneficial Requirement Overly Neglected in TVET Institutions. International Journal of Vocational Education and Training Research. Vol. 5, No. 2, 2019, pp. 48-52. doi: 10.11648/j.ijvetr.20190502.12

Received: September 5, 2019; Accepted: September 25, 2019; Published: October 17, 2019

\begin{abstract}
This paper focuses on school production unit/consultancy services with special reference to its many-sided beneficial requirement that is overly neglected in TVET institutions. The study adopted survey research design. Questionnaires were used to seek opinions of TVET technical college teachers and lecturers in tertiary TVET institutions on functional TVET school production units/consultancy services and the challenges hindering the establishment. The functional production units/consultancy services in TVET institutions in the study include poultry farms, fishery, clothing and textile, catering craft practices, data processing, among others. Contrarily, feed production, salesmanship, cosmetology, leather goods manufacturing and repair, GSM maintenance and repair were not functional at all in all the institutions surveyed. Challenges found to hinder school production/consultancy services of TVET institutions were: lack of organizational vision for productivity (3.39 \pm 0.63$)$, poor perception of school production units/consultancy services $(3.36 \pm 0.65)$, lack of manpower to drive the establishment (3.24 \pm 0.66$)$ and perceived problems of integrating industries in TVET programmes (2.96 \pm 0.94$)$. The study concludes therefore, that the benefits of school production units/consultancy services in TVET institutions are enormous, making it a fundamental requirement that should not be neglected. Thus, overcoming the challenges hindering the establishment of school production units/consultancy services will reflect in the quality of graduates turned out into the society and would eventually minimize to the barest minimum the need to retrain TVET graduates by employers.
\end{abstract}

Keywords: TVET, Pedagogical Profession, Technical Education, Vocational Education, Dual System

\section{Introduction}

Technical Vocational Education and Training (TVET) has been highly accepted as a form of education with the ability to inculcate work ready knowledge, skills and attitude. TVET has been adopted and practiced as a skill development system upon which industrialization of countries depend [1]. More so, TVET practices have taken many forms/approaches across countries. Example is the German dual system where there is constant supply of high level skilled workers into the industrial sector through concerted efforts of the government, regional leaderships and private sectors both in funding and setting of educational agenda [2-5]. Dual TVET system, according to Remington [3], refers to the practice of dividing vocational education and training between school-based and workplace-based sites where $70 \%$ of the time spent by trainees is devoted to practical training (both on the job and in dedicated training facilities) and $30 \%$ in institutions of learning. This practice has positioned Germany to have 
unemployment rate of $3.2 \%$ as at February, 2019 [6]. Although replicating the results of the Dual TVET system has been difficult in other countries [3], establishing school production units/consultancy services in TVET institutions would afford a replica of the benefits.

In Nigeria, TVET is fully accepted and funded by the government aside pockets of donor agencies. The Federal Government of Nigeria [FGN] in her National Policy on Education mandated the establishment of school production units across skill areas in TVET institutions (also called consultancy services in tertiary TVET institutions) [7]. School production unit refers to a portion or part of the school workshop/laboratory where materials and human inputs are combined for the creation of goods, items or provision of services [8]. According to Ogumbe [9], it is an industrial sector of the learning institutions where students work under the supervision of qualified instructors to make/maintain household goods/products and other allied technical services. Production units in TVET institutions are beyond just laboratory or workshop, it is an established avenue to ensure constant practice of theories learnt in classroom through meaningful engagement of learners in real life encounters amidst customers and masters of the skills. School production unit can also be called school-based entrepreneurship [SBE] [10, 11]. The authors defined SBE as an organized centre for vocational school students to make/manufacture or render services to the school or community. The school production unit setting is further described as consultancy services in tertiary TVET institutions in Nigeria.

Consultancy services refer to avenue created to utilize researches, manpower and equipment available in TVET institutions for learning and commercial purposes. Chukwu \& Omeje [12] stated that consultancy services in TVET tertiary institutions represent high-level research-based professional business establishments catering for the development of small and medium scale enterprises (SMEs), providing professional and technical support in products development and improvement as well as providing platform for efficient partnership with technologically intensive industries. It is institutional based enterprise with dual purpose of ensuring all-round training for the students and revenue generation for the institutions. Expertise available in learning institutions can only be fully deployed to the benefit of the school, learners and the communities through consultancy services [13]. The avenue to fully develop and certify learners in both theory and practical skills are possible when school production units/consultancy services are established in TVET institutions.

Whether in secondary or tertiary TVET institution, school production units/consultancy services afford many benefits. The benefits include: synergizing theory and practice, providing on-the-job training to students, certifying students for graduation in skilled areas [7, 9, 14]. In other words, the complaints of employers about certified graduates without salable skills can become a thing of the past when school production units/consultancy services are established and made functional. Students would have the opportunity to interact with customers on-the-job and acquire certificates in skills areas matching their trainings. More so, there is possibility of increasing institutions' internally generated revenue through functional school production units/consultancy services, while the establishments serve the purpose of industrial work experience placements for many a student, and a part-time employment outfit for indigent students (an aspect of employment rarely seen in our institutions) [8]. Eka, Panjaitan and Muslim [10] states that school production units/consultancy services would provide linkages to contexts and resources not covered in the curriculum; target and solve identified community/school challenges through creative research and skill infusions; increase students' confidence, customer relationship, collaborative skills and problem solving abilities when challenged. The school production units/consultancy services are simply world of work brought into learning institutions for dual purposes, hence the establishments can as well engage in training programmes not otherwise covered in the curriculum for skills and knowledge [10]. The benefits of school production units/consultancy services are enormous and cannot be overemphasized. But the injunction to have it established in institutions is grossly neglected.

The non-adherence of the TVET institutions in Nigeria to establish school production units/consultancy services is tantamount to neglect of a vital training requirement and subsequently subscribing to perpetual dependency culture. Imagine what it would be that every TVET institution is running a functional school production units/consultancy services in just one skill area. Imagine if every school takes advantage of the most abundant resources in their locale and explores to develop same using every manpower and equipment at their disposal. Also, what will be if education for work is exemplified in schools of training? How is it that those who teach students to graduate and become self-reliant are never looking inwards towards being self-sustaining as an institution? Accordingly, closing the gap between education in school/theory and demand of world of work/practice is at the mercy of functional school production unit/consultancy services overly neglected in TVET institutions. In observing the dearth of school production units/consultancy services and its absolute non-existence in many TVET institutions, this study therefore seeks to ascertain the functional areas and challenges hindering the establishment of school production units/consultancy services across skill areas in TVET institutions.

\subsection{Research Questions}

The following questions guided the study:

1. What areas of school production units/consultancy services are functional in TVET institutions?

2. What are the challenges hindering the establishment of school production units/consultancy services in TVET institutions? 


\subsection{Hypothesis}

Ho1: The responses Technical College Teachers and University Lecturers on the challenges hindering the establishment of school production units/consultancy services in TVET institutions do not differ significantly.

\section{Methodology}

The study adopted a descriptive survey research design. Survey research design was used to seek opinions of TVET Technical College Teachers and Lecturers in tertiary TVET institutions on functional TVET school production units/consultancy services and the challenges hindering the establishment. Area of study was Enugu State, Nigeria; comprising 27 secondary and 6 tertiary TVET institutions. The population for the study was 260 teachers and lecturers in 5 technical colleges and 2 tertiary institutions within three different major towns in Enugu State namely Udi, Nsukka and Enugu metropolis. The sample size was statistically determined using Taro Yamane formula for finite population, simple random sampling was used to select the 158 respondents used for the study [15]. The instrument used for the study was a structured questionnaire, validated and tested for reliability. The questionnaire has two sections: A and B; section A elicited demographic information of the respondents and section B had 46 item based on the research questions. In Section $B$, question 1 sought responses of TVET teachers and lecturers on functional areas of school production units/consultancy services in their institutions with responses of Functional $=2$ and Not Functional $=1$; the responses to question 2 on challenges of production units/consultancy services, were designed based on 4-point scale with responses of: Strongly Agree, $S A=4$; Agree, $A=$ 3; Disagree, $D=2$; and Strongly Disagree, $S D=1$.

Data collection was carried out by the researchers through direct instrument administration and collection. However, $72 \%$ of the instrument representing 114 copies were returned and was used for data analysis. Data collected were analyzed using simple percentages for the demographic information and research question 1 , while mean and standard deviation were used to answer research questions 2. T-test was used in testing the null hypothesis at 0.05 level of significance. Based on the 4-point rating scale, the mean of the scale is 2.50 . Therefore, mean scores of 2.50 and above were regarded as indication of 'Agreed', while mean scores below 2.50 were regarded as 'Disagreed.' Any item where the p-value is greater than 0.05 , the hypothesis of no significant difference was upheld at 0.05 level of significance; but where the p-value is less than 0.05 , the hypothesis of no significant difference was rejected.

\section{Discussion of Findings}

\subsection{Demographics of the Respondents}

Table 1 presents the demographic information on the respondents. There were 44 respondents, representing $38.6 \%$ from technical colleges while 70 respondents being $61.4 \%$ were from tertiary institutions. In gender distribution, there were 36 females with $31.6 \%$ and 78 males $68.4 \%$ involved in the study. Among the TVET areas covered, Agricultural Education showed 9 respondents, with 7.9\%; Business Education, 15 respondents occupying 13.2\%; Computer Education had 14 respondents with 12.3\%; Building and woodwork grouped together had 26 respondents with $22.8 \%$; Electrical/Electronic had 18 respondents with $15.8 \%$; Home Economics had 11 respondents which occupied 9.6\%; Metal works and Automechanics had 14 respondents with $12.3 \%$; Creative Arts, 5 respondents with $4.4 \%$ and other areas not initially captured were indicated by 2 respondents which occupied $1.8 \%$. There is a wide coverage and inclusion of TVET personnel across different areas of TVET in the study which helps in getting a clearer picture of the functionalities of school production units/consultancy services across skill areas.

Table 1. Demographic information of the respondents.

\begin{tabular}{llll}
\hline Class & & $\boldsymbol{N}$ & Percentage (\%) \\
\hline \multirow{2}{*}{ Institution } & Technical College & 44 & 38.6 \\
& Tertiary & 70 & 61.4 \\
Gender & Female & 36 & 31.6 \\
& Male & 78 & 68.4 \\
& Agricultural Education & 9 & 7.9 \\
& Business Education & 15 & 13.2 \\
TVET Area & Computer Education & 14 & 12.3 \\
& Building \& Woodwork & 26 & 22.8 \\
& Electrical/Electronic & 18 & 15.8 \\
Others & Home Economics & 11 & 9.6 \\
& Metal Works/Automechanics & 14 & 12.3 \\
& Creative Arts & 5 & 4.4 \\
\end{tabular}

\subsection{Functional School Production Units and Consultancy Services}

The data in Table 2 shows the functional and non- functional production units/consultancy services in TVET institutions. The functional areas include poultry farms, fishery, clothing and textile, catering craft practices, data processing, hardware maintenance, machine woodwork, carpentry and joinery as well as furniture making; whereas 
areas such as: feed production, salesmanship, cosmetology, leather goods manufacturing and repair, GSM maintenance and repair etc. were not functional at all in all the institutions involved. The average percent of the overall items indicated that $27.99 \%$ of the school production units/consultancy services were functional while $72.01 \%$ were not functional. The poor functionality record indicated poor interests of institutions in engaging in production units and consultancy services for effective skill delivery among other benefits.

Table 2. Functional areas of production units/consultancy services in TVET institutions.

\begin{tabular}{|c|c|c|c|c|c|}
\hline $\mathbf{S} / \mathbf{N}$ & School Production Units/Consultancy Services & $N$ & $F(\%)$ & $N$ & $N F(\%)$ \\
\hline 1 & Poultry farms & 73 & $(64.0)$ & 41 & $(36.0)$ \\
\hline 2 & Feed Production & 0 & $(0.0)$ & 114 & $(100)$ \\
\hline 3 & Animal husbandry & 29 & $(25.4)$ & 85 & $(74.6)$ \\
\hline 4 & Fishery & 72 & $(63.2)$ & 42 & $(36.8)$ \\
\hline 5 & Agro-processing & 33 & $(28.9)$ & 81 & $(71.1)$ \\
\hline 6 & Marketing & 47 & $(41.2)$ & 67 & $(58.8)$ \\
\hline 7 & Salesmanship & 0 & $(0.0)$ & 114 & $(100)$ \\
\hline 9 & Tourism & 3 & $(2.6)$ & 111 & $(97.4)$ \\
\hline 10 & Leather goods manufacturing and repair & 0 & $(0.0)$ & 114 & $(100)$ \\
\hline 11 & Cosmetology & 0 & $(0.0)$ & 114 & $(100)$ \\
\hline 12 & Clothing and textile & 73 & $(64.0)$ & 41 & $(36.0)$ \\
\hline 13 & Dying and bleaching & 0 & $(0.0)$ & 114 & $(100)$ \\
\hline 14 & Garment making & 33 & $(28.9)$ & 81 & $(71.1)$ \\
\hline 15 & Catering craft practice & 76 & $(66.7)$ & 38 & $(33.3)$ \\
\hline 17 & Hardware maintenance & 73 & $(64.0)$ & 41 & $(36.0)$ \\
\hline 18 & Software development & 68 & $(59.6)$ & 46 & $(40.4)$ \\
\hline 19 & Electrical installation and maintenance work & 34 & $(29.8)$ & 80 & $(70.2)$ \\
\hline 20 & Radio, TV and Electronic Servicing & 48 & $(42.1)$ & 66 & $(57.9)$ \\
\hline 21 & GSM maintenance and repairs & 0 & $(0.0)$ & 114 & $(100)$ \\
\hline 22 & Block laying, brick laying and concrete work & 0 & $(0.0)$ & 114 & $(100)$ \\
\hline 23 & Painting and decorating & 0 & $(0.0)$ & 114 & $(100)$ \\
\hline 24 & Plumbing and pipe fitting & 0 & $(0.0)$ & 114 & $(100)$ \\
\hline 25 & Machine woodworking & 70 & (61.4) & 44 & $(38.6)$ \\
\hline 26 & Carpentry and joinery & 72 & $(63.2)$ & 42 & $(36.8)$ \\
\hline 27 & Furniture making & 70 & $(61.4)$ & 44 & $(38.6)$ \\
\hline 28 & Upholstery & 30 & $(26.3)$ & 84 & $(73.7)$ \\
\hline 29 & Auto body repair and spray painting & 0 & $(0.0)$ & 114 & $(100)$ \\
\hline 30 & Auto Electrical work & 29 & $(25.4)$ & 85 & $(74.6)$ \\
\hline 31 & Auto mechanical work & 41 & $(36.0)$ & 73 & $(64.0)$ \\
\hline 32 & Auto spare parts merchandising & 0 & $(0.0)$ & 114 & $(100)$ \\
\hline \multicolumn{2}{|c|}{ Average percent of overall items } & \multicolumn{2}{|c|}{$(27.99)$} & \multicolumn{2}{|c|}{$(72.01)$} \\
\hline
\end{tabular}

Key: $\mathrm{N}=$ number of respondents; $\mathrm{F}=$ Functional; NF $=$ Not Functional.

\subsection{Challenges Hindering the Establishment of School Production Units/Consultancy Services}

Table 3 shows Mean, standard deviation and t-test analysis of the responses of teachers and lecturers on the challenges hindering the establishment of school production units or consultancy services. The table shows that all the 12-items had mean responses above 2.5 benchmark, hence the respondents agreed to the challenges hindering the establishment of school production units or consultancy services. Also, the overall results indicated a cluster mean of 3.20 with 0.32 standard deviation, showing a total agreement without disparity among the respondents.

The T-test analysis of the null hypothesis in table 3 shows a not significant response in 11 of the 12 items with $p$-values greater than 0.05 . The non-agreement of the teachers and lecturers in the challenge of 'problem of income disbursement' (item 11) indicates that in school where school production units/consultancy services are functional there must a working document spelling out the modalities for revenue disbursement [8]. Furthermore, table 3 reveals an overall result showing p-value (0.29) greater than 0.05 , at 0.05 level of significant and 112 degree of freedom, therefore the null hypothesis was upheld. Hence, there is no significant difference in the mean responses of technical colleges teachers and tertiary TVET institution lecturers on the challenges hindering the establishment of school production units/consultancy services in TVET institutions. 
Table 3. Challenges hindering the establishment of school production units/consultancy services in TVET institutions.

\begin{tabular}{|c|c|c|c|c|c|c|c|c|}
\hline $\mathbf{S} / \mathbf{N}$ & Challenges of School Production Units/Consultancy Services & $N$ & $\bar{x}$ & $S D$ & Rem. & $t-c a l$ & Sig. & Rem. \\
\hline 1 & Lack of organizational vision for productivity & 114 & 3.39 & 0.63 & A & -1.11 & 0.27 & $\mathrm{NS}$ \\
\hline 2 & Poor perception of school production units/consultancy services & 114 & 3.36 & 0.65 & A & 0.24 & 0.81 & NS \\
\hline 3 & Lack of basic equipment in relevant areas & 114 & 3.47 & 0.61 & A & -1.63 & 0.11 & NS \\
\hline 4 & Lack of manpower to drive the establishment & 114 & 3.24 & 0.66 & A & 0.42 & 0.68 & NS \\
\hline 5 & Perceived extra labour or burden on staff members & 114 & 3.12 & 0.78 & A & 0.59 & 0.55 & NS \\
\hline 6 & Lack of interest in running establishment & 113 & 3.20 & 0.85 & A & -0.46 & 0.64 & NS \\
\hline 7 & Lack of skills needed for SME & 114 & 3.12 & 0.87 & $\mathrm{~A}$ & 1.19 & 0.24 & NS \\
\hline 8 & Insufficient fund for seed capital & 114 & 3.27 & 0.88 & A & 0.21 & 0.83 & NS \\
\hline 9 & Comfortability with the status quo & 114 & 2.93 & 0.85 & A & 1.81 & 0.07 & NS \\
\hline 10 & Time management issues & 114 & 3.03 & 0.83 & $\mathrm{~A}$ & 0.50 & 0.62 & NS \\
\hline 11 & Problem of income disbursement & 114 & 3.32 & 0.79 & A & 3.27 & 0.00 & $\mathrm{~S}$ \\
\hline 12 & Perceived problems of integrating industries in TVET programmes & 114 & 2.96 & 0.94 & A & -0.11 & 0.91 & NS \\
\hline \multicolumn{2}{|r|}{ Overall Results } & 114 & 3.20 & 0.32 & A & 1.06 & 0.29 & NS \\
\hline
\end{tabular}

Key: $\mathrm{N}=$ Number of Respondents; $\bar{x}=$ Mean; $\mathrm{SD}=$ Standard Deviation; Rem. $=$ Remark; -cal $=$ Calculated $\mathrm{t}$-value; Sig. $=$ Significant $\mathrm{p}$-value; $\mathrm{df}=(2,112)$.

\section{Conclusion}

The benefits of school production units/consultancy services in TVET institutions are enormous, making it a fundamental requirement that should not be neglected. The level of attention given to the establishment of these dual purpose ventures would ultimately reflect in the quality of graduates turned out into the society and would eventually minimize to the barest minimum the need to retrain TVET graduates by employers. Overcoming the challenges hindering the establishment of school production units/consultancy services is vital in ensuring smooth takeoff and running of the ventures, while showing students the way to self-reliance. There is no doubt that exploring the deliverables of the many-sided benefits in school production units/consultancy services, overly neglected, is a sure way of showcasing that TVET is indeed education for work.

\section{References}

[1] Chete, L. N., Adeoti, J. O., Adeyinka, F. M. \& Ogundele, O. (2014). Industrial development and growth in Nigeria: Lessons and challenges. WIDER Working Paper 2014/019. Helsinki: UNU-WIDER.

[2] Remington, T. F. (2017). Public-private partnerships in VET: Translating the German model of dual education. Moscow: HSE Publishing House.

[3] Remington, T. F. (2018). Public-private partnerships in TVET: Adapting the dual system in the United States. Journal of Vocational Education and Training, 70 (4), 497-523.

[4] Hawley, J. (2005). Public private partnerships in vocational education and training: international examples and models. Ohio: World Bank and Ohio State University USA.

[5] Gill, I. S., Fluitman, F. \& Dar, A. (2000). Vocational education and training reform: Matching skills to markets and budgets. World Bank/Oxford University Press: Washington DC.

[6] Trading Economics (2019). Germany unemployment rate.
Retrieved

from https://tradingeconomics.com/germany/unemployment-rate, accessed 03/09/2019.

[7] Federal Republic of Nigeria, [FRN], (2013). National Policy on Education ( $6^{\text {th }}$ Edition). Lagos-Nigeria: NERDC press.

[8] Chukwu, D. U. \& Omeje, H. O. (2017). School Production Unit: A stride towards promoting entrepreneurship in post-oil boom economy. A conference paper presented at the National Conference of the Association of Vocational Educators of Nigeria, held at University of Calabar between $13^{\text {th }}-17^{\text {th }}$ June, 2017.

[9] Ogumbe, B. E. (2015). Assessment of mechanical engineering craft practice production units in technical colleges in the south - south zone of Nigeria (Unpublished Ph. D. thesis). Department of Industrial Technical Education, University of Nigeria, Nsukka.

[10] Daryanto, E., Panjaitan, K. \& Muslim, (2015). Evaluation of entrepreneurship in unit production vocational high school (SMK) Simalungun Northern Sumatra. American Journal of Educational Research, 3 (9), 1072-1076. doi: 10.12691/education-3-9-2.

[11] Mahfud, P. (2012). Praksis pembelajaran kewirausahaan pada unit produksi jasa Boga. Jurnal Pendidikan Vokasi, 2 (1), 2739.

[12] Chukwu, D. U. \& Omeje, H. O. (2018). Strengthening partnership affordances between TVET institutions and industry through production unit/consultancy services. Journal of Association of Vocational \& Technical Educators of Nigeria, 23 (1), 169-179.

[13] Kirby, D. A. \& Dylan J. E. (1997). Small technology-based professional consultancy services in the United Kingdom. Serv. Ind. J. 17, 155-172.

[14] Ananda, A. F. \& Mukhadis, A. (2016). Production unit as entrepreneurship, cooperation business and industrial world with the school for the development of vocational student entrepreneurship mindset. AIP Conference Proceedings, 1778 (1), 1-10.

[15] Yamane, T. (1967). Statistic: An introductory analysis (2nd ed.). New York: Harper and Row. 